\title{
obituary
}

\section{P.C. Sylvester-Bradley}

Peter Colley Sylvester-Bradley, the F. W. Bennett Professor of Geology at the University of Leicester died unexpectedly at Weston-Super-Mare on 17 April 1978, at the end of a student vacation field course, at the age of 64 . Tragically his death came only five months before he was due to retire and continue with his researches in micropalaeontology, fossil oysters and evolution-all subjects in which he had attained international eminence. With his death, British palaeontology has lost one of its most distinguished scholars.

$\mathrm{He}$ was born on 21 May 1913 at Pinhoe, Devon and went to Haileybury College, Herts. where he was a science prize winner. He graduated in geology at the University of Reading where he cultivated a range of other scientific interests: for example he became the first editor of the Proceedings of the Reading and District Natural History Society. $\mathrm{He}$ started his geological research on the Purbeck Beds of Dorset and became interested in their great variety of ostracods, a neglected group of microfossils on which he was later to become one of the world's leading authorities.

His first appointment was to found a geology department at the Agricultural College of Seale Hayne in Devon. This was interrupted by the second world war and, after a brief period at the British Museum, he joined the Royal Navy. After the war he became a lecturer, later senior lecturer, in palaeontology at the University of Sheffield, except for the year 1955-56 when he was Rose Morgan Professor at the University of Kansas. In 1959 he became the first F. W. Bennett Professor of Geology at the University of Leicester, a post which he held with great distinction. He built up a department which now has a high international standing in the major branches of geology and which has produced a number of eminent scholars. He took a personal interest in all the activities of his department and his scientific interests consequently broadened considerably.

His principal field of interest was in micropalaeontology, and in particular the internal and external structures of ostracods. These studies took a great leap forward when he applied the newly-invented scanning electron microscope to their study. This provided a considerable amount of new data of high quality which he kept improving by careful experimentation. His work was published in the form of a stereo-atlas of ostracod shells, a new and improved form of palaeontological publication. He applied his expertise on ostracods to the history of the Mediterranean and to enhance our understanding of the Jurassic geology of Britain.

Another major life-long interest was the Jurassic oysters from Europe and to some extent from North America, from which he developed his ideas on iterative evolution. He wrote and lectured extensively about aspects of evolution rainging from the origin and evolution of life to the evolution of ethics. He contributed a great deal to the ideas on the volcanic environments in which life may have originated and directed attention to the possibility of evidence for the earliest forms of life being found in low-grade metamorphic areas. The geology of carbon and the origin of oil were related interests. $\mathrm{He}$ was a leading figure in the world of systematics and wrote extensively about the numerical approach to taxonomy, the concept of species, subspecies, superspecies, form genera, diversity and stratigraphic nomenclature.

He was active in over twenty scientific societies. At various times he was Chairman of the British Micropalaeontological Society, President of the Systematics Association, Vice-President of the International Palaeontological Association and of the Palaeontological Association. He also served as editor of a number of palaeontological and geological publications

Peter Sylvester-Bradley was a brilliant lecturer and was always in great demand. His lectures on a wide range of subjects, were always very vivid and generally contained the latest ideas which stretched his students and staff to the limit. He had very wide interests outside the field of geology. He was a keen landscape gardener. $\mathrm{He}$ maintained active interests in conservation. travel, country wines and the arts, particularly operatic music. $\mathrm{He}$ was well-known in Leicester through his activities with the Haldane Society, The Leicestershire Trust for Nature Conservation and the Leicester Literary and Philosophical Society, over all of which he presided. A devout Christian, he was a regular lay-preacher at the Stoughton village church. $\mathrm{He}$ was regarded with the greatest affection by all members of his department and will be sadly missed by his colleagues throughout the University and friends in many parts of the world. He leaves his wife, Joan, a fellow student at Reading whom he married in 1945, a daughter, Rosemary, and three sons, Rowan, Roger and Benjamin.

M. A. Khan

\section{Sir Harry Jephcott}

Sir Harry Jephcott, who died on 29 May 1978, at the age of 87 , played a very important role in the development of the British pharmaceutical industry and in the applications of science to industrial needs.

Born at Redditch in 1891 he graduated in chemistry in 1915 and worked in the Laboratory of the Government Chemist to earn sufficient to enable him to study and qualify as pharmaceutical chemist in 1916. In 1918 he joined Glaxo and there began a remarkable career first as chemist then as General Manager, Managing Director, Chairman and Managing Director of an organisation originally manufacturing and marketing baby foods and developing to an organisation which, on his retirement in 1963 was the major producer in this country of penicillin, streptomycin, cortisone, hydrocortisone. poliomyelitis vaccine and other immunological products. It is a remarkable development reflecting the skill and influence of a remarkable man.

In his book The First Fifty Years, published for private circulation in 1970, Jephcott recalls the history of the Nathan organisation and the beginnings of the pharmaceutical interests of Glaxo. But it was the years of the Second World War that revealed Jephcott's potential. First as manufactured foods adviser to the Ministry of Food he brought a new concept to the definition of composition, description and labelling of manufactured foods that had the encouragement throughout of Lord Woolton. Simultaneously Jephcott found time and energy to direct the participation of Glaxo in the development of manufacture of peni- 